\title{
Synthesis, X-ray Crystal Structure and Theoretical Calculations of Antileishmanial Neolignan Analogues
}

\author{
Josenaide P. do Nascimento, ${ }^{a}$ Lourivaldo S. Santos, ${ }^{a}$ Regina Helena A. Santos, ${ }^{b}$ \\ Érica Tozzo, ${ }^{b}$ Janaina G. Ferreira, ${ }^{b, c}$ Maria Carolina L. do Carmo, ${ }^{a}$ \\ Davi S. B. Brasil ${ }^{a}$ and Cláudio N. Alves $*, a$
}

\author{
anstituto de Ciências Exatas e Naturais, Universidade Federal do Pará, Rua Augusto Corrêa 01, \\ 66075-110 Belém-PA, Brazil \\ ${ }^{b}$ Instituto de Química de São Carlos, Universidade de São Paulo, Av. do Trabalhador São-carlense \\ 400, CP 780, 13560-970 São Carlos-SP, Brazil
}

'Instituto de Química de Araraquara, Universidade Estadual Paulista, Rua Francisco Degni s/n, 14800-900 Araraquara-SP, Brazil

\begin{abstract}
A síntese e a estrutura cristalina por difração de raios- $\mathrm{X}$ de dois análogos de neolignanas, 2-(4-clorofenil)-1-feniletanona (20) e 2-[tio(4-clorofenil)]-1-(3,4-dimetoxifenil)propan-1-ona (12) são descritas. O composto 12 apresenta atividade intracelular contra Leishmania donovani e Leishmania amazonensis de amastigotas que causam a leishmaniose tegumentar e visceral. Além disso, a teoria do funcional de densidade (DFT) com o funcional híbrido B3LYP foi empregado para calcular um conjunto de descritores moleculares para dezenove análogos sintéticos de neolignanas com atividades antileishmaniose. Posteriormente, a análise discriminante stepwise foi realizada para investigar possíveis relações entre a estrutura molecular e atividades biológicas. Por meio dessa análise os compostos foram classificados em dois grupos ativos e inativos de acordo com seu grau de atividade biológica, e as propriedades mais importantes foram as cargas de alguns átomos, a afinidade eletrônica e o ClogP.
\end{abstract}

The synthesis and X-ray crystal diffraction structure of two analogues of neolignans, 2-(4-chlorophenyl)-1-phenylethanone (20) and 2-[(4-chlorophenyl)thio]-1-(3,4-dimethoxyphenyl) propan-1-one (12) is described. The compound $\mathbf{1 2}$ presents activity against intracellular Leishmania donovani and Leishmania amazonensis amastigotes that cause cutaneous and visceral leishmaniasis. In addition, the density functional theory (DFT) with the B3LYP hybrid functional was employed to calculate a set of molecular descriptors for nineteen synthetic analogues of neolignans with antileishmanial activities. Afterwards, the stepwise discriminant analysis was performed to investigate possible relationship between the molecular descriptors and biological activities. Through this analysis the compounds were classified into two groups active and inactive according to their degree of biological activities, and the more important properties were charges on some key atoms, electronic affinity and $\mathrm{Clog}$.

Keywords: neolignans, antileishmanial, B3LYP, X-ray crystal structure

\section{Introduction}

The leishmaniases are parasitic diseases caused by protozoa of the genus Leishmania and remain a severe public health problem, particularly in many tropical and subtropical regions. The infection is transmitted by bite from female sandflies, which are of the genus Phlebotomus

*e-mail: nahum@ufpa.br or Lutzomyin. This infection has several diverse clinical manifestations: cutaneous, mucosal and most notably visceral leishmaniasis, and is caused by Leishmania amazonensis, Leishmania braziliensis, and Leishmania donovani species. ${ }^{1-4}$ An estimated 1.5 to 2 million new cases of leishmaniasis occurs each year in the world, which in the visceral manifestation is often fatal if untreated..$^{5-9}$ Unfortunately non-availability of satisfactory chemotherapeutic agents and failure to develop an effective 
vaccine are considered to be two stumbling blocks in the combat of this disease. ${ }^{10}$

Treatment approaches and responses to chemotherapy vary by regions. Antimony remains the therapeutic cornerstone in all regions; however, antimony is expensive, toxic and requires administration of high doses resulting in serious side effects. ${ }^{11-13}$ Therefore, there remains an urgent need for development of less toxic drugs that are effective against all forms of leishmaniases. The search of new drugs against leishmaniasis, potentially compounds and their derivatives have been described in the literature. ${ }^{14-16}$

Neolignans are groups of compounds that show a wide range of biological effects including antifungal, ${ }^{17-19}$ anti-schistosomal, ${ }^{20-23}$ antiplasmodial, ${ }^{24}$ trypanocidal,,${ }^{25-27}$ antibacterial, ${ }^{28}$ anti-PAF, ${ }^{29,30}$ antipsychotic, ${ }^{31}$ antioxidant, ${ }^{32,33}$ activities, and biological activity against Escherichia coli, ${ }^{34,35}$ Paracoccidioides brasiliensis. ${ }^{36}$ Usually, neolignans are organic dimmers derived from oxidative coupling of allyl and propenyl phenols. ${ }^{16,22}$ Previous studies have evaluated the antileishmanials activities of twenty-two sulfur and oxygen synthetic analogues of neolignans against parasite species that cause cutaneous and visceral Leishmaniasis..$^{14,15}$ These compounds were synthesized and their activities against both intracellular amastigotes of $L$. donovani and L. amazonensis were compared.

In the work reported here, two neolignan analogues were synthesized, the 2-[(4-chlorophenyl)thio]-1(3,4-dimethoxyphenyl)propan-1-one (12) and the 2-(4-chlorophenyl)-1-phenylethanone (20), and their molecular structures were obtained by X-ray diffraction (Figure 1 and 2). The synthesis of 2-[(4-chlorophenyl) thio]-1-(3,4-dimethoxyphenyl)propan-1-one (12) was described in previous studies ${ }^{14,15}$ and their biological activity was evaluated by Aveniente $e t$ al. ${ }^{14}$ However, the $\mathrm{X}$-ray experimental results for this molecule together with synthesis and crystallographic of 2-(4-chlorophenyl)-1phenylethanone (20) are described for the first time here. In addition, the DFT method was employed in order to calculate forty-one physicochemical descriptors, including electronic, steric and hydrophobic of nineteen synthetic analogues of neolignans reported by Aveniente et al. ${ }^{14}$ (see Figure 3 and Table 1). Recently, we successfully used molecular descriptors in structure-activity relationship (SAR) studies of neolignan compounds with antischitosomal activity, ${ }^{20,21}$ antifungal activity, ${ }^{37}$ and synthetic neolignans with biological activity against Escherichia coli $^{34}$ and Paracoccidiodes brasiliensis. ${ }^{36}$ These descriptors are successful and well accepted. ${ }^{38-45}$

Our purpose is to investigate, in a qualitative way, the structure activity relationship of neolignan compounds using quantum chemical descriptors. Stepwise discriminant<smiles>COc1ccc(C(=O)C(C)Sc2ccc(Cl)cc2)cc1OC</smiles>

(a)



(b)

Figure 1. Structural skeleton numbering (a) and ORTEP view of molecule 12 (b), with the atom labelling scheme and thermal ellipsoids vibration with $50 \%$ of probability.
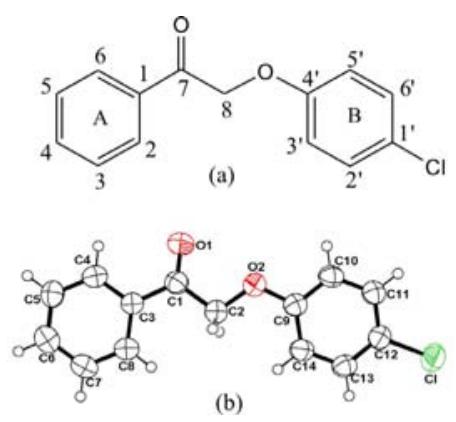

Figure 2. Structural skeleton numbering (a) and ORTEP view of molecule 20 (b), showing the atom labelling scheme and the $50 \%$ probability thermal vibration ellipsoids.

analysis (SDA) was employed to analyze the data set, in order to build models for predicting the relationship between these descriptors and the antileishmanial activities of the compounds.

\section{Experimental}

\section{Instruments}

${ }^{1} \mathrm{H}$ NMR (100 MHz) spectrum was recorded on a Varian XL-100 spectrometer. Chemical shifts were reported in ppm from tetramethylsilane on the $\delta$ scale and coupling constants $J$ are expressed in Hz. IR spectra was recorded in $\mathrm{KBr}$ film and measured with a Bomen model MB series II spectrophotometer. Electrothermal melting point apparatus are uncorrected.

\section{General}

Within the great structural variety of neolignans the $\beta$-ketoether, $\beta$-ketosulfide, $\beta$-ketosulfoxide and 
Table 1. Biological response for the neolignans studied. See Figure 1 for the positions of substituents ' $R$ ' listed in the first line of the table

\begin{tabular}{|c|c|c|c|c|c|c|c|c|c|}
\hline Molecules & Type & $\mathrm{R}^{1}$ & $\mathrm{R}^{2}$ & $\mathrm{R}^{3}$ & $\mathrm{R}^{4}$ & $\mathrm{R}^{5}$ & $\mathrm{R}^{6}$ & $\begin{array}{c}\text { Leishmania } \\
\text { donovani }\end{array}$ & $\begin{array}{l}\text { Leishmania } \\
\text { amazonensis }\end{array}$ \\
\hline 1 & A & $\mathrm{H}$ & $\mathrm{H}$ & $\mathrm{H}$ & $\mathrm{H}$ & $\mathrm{H}$ & $\mathrm{H}$ & active & active \\
\hline 2 & A & $\mathrm{H}$ & $\mathrm{Cl}$ & $\mathrm{H}$ & $\mathrm{CH}_{3} \mathrm{~S}$ & $\mathrm{H}$ & $\mathrm{H}$ & active & active \\
\hline 3 & A & $\mathrm{CH}_{3} \mathrm{O}$ & $\mathrm{CH}_{3} \mathrm{O}$ & $\mathrm{H}$ & $\mathrm{H}$ & $\mathrm{Cl}$ & $\mathrm{H}$ & inactive & active \\
\hline 4 & A & $\mathrm{CH}_{3} \mathrm{O}$ & $\mathrm{CH}_{3} \mathrm{O}$ & $\mathrm{CH}_{3}$ & $\mathrm{CH}_{3} \mathrm{O}$ & $\mathrm{H}$ & $\mathrm{CH}_{3} \mathrm{O}$ & active & active \\
\hline 5 & A & $\mathrm{CH}_{3} \mathrm{O}$ & $\mathrm{CH}_{3} \mathrm{O}$ & $\mathrm{CH}_{3}$ & $\mathrm{CH}_{3} \mathrm{O}$ & propenyl & $\mathrm{H}$ & active & active \\
\hline 6 & B & $\mathrm{H}$ & $\mathrm{H}$ & $\mathrm{H}$ & $\mathrm{Cl}$ & - & - & active & active \\
\hline 7 & B & $\mathrm{H}$ & $\mathrm{Cl}$ & $\mathrm{H}$ & $\mathrm{Cl}$ & - & - & inactive & active \\
\hline 8 & B & $\mathrm{H}$ & $\mathrm{H}$ & $\mathrm{CH}_{3}$ & $\mathrm{H}$ & - & - & active & active \\
\hline 9 & B & $\mathrm{H}$ & $\mathrm{H}$ & $\mathrm{CH}_{3}$ & $\mathrm{NH}_{2}$ & - & - & active & inactive \\
\hline 10 & B & $\mathrm{H}$ & $\mathrm{H}$ & $\mathrm{CH}_{3}$ & $\mathrm{Cl}$ & - & - & active & active \\
\hline 11 & B & $\mathrm{CH}_{3} \mathrm{O}$ & $\mathrm{CH}_{3} \mathrm{O}$ & $\mathrm{CH}_{3}$ & $\mathrm{CH}_{3}$ & - & - & active & active \\
\hline 12 & B & $\mathrm{CH}_{3} \mathrm{O}$ & $\mathrm{CH}_{3} \mathrm{O}$ & $\mathrm{CH}_{3}$ & $\mathrm{Cl}$ & - & - & active & active \\
\hline 13 & $\mathrm{C}$ & $\mathrm{H}$ & $\mathrm{H}$ & $\mathrm{H}$ & $\mathrm{H}$ & - & - & inactive & active \\
\hline 14 & D & $\mathrm{H}$ & $\mathrm{H}$ & $\mathrm{CH}_{3}$ & $\mathrm{Cl}$ & - & - & inactive & inactive \\
\hline 15 & D & $\mathrm{CH}_{3} \mathrm{O}$ & $\mathrm{CH}_{3} \mathrm{O}$ & $\mathrm{CH}_{3}$ & $\mathrm{CH}_{3}$ & - & - & inactive & active \\
\hline 16 & E & $\mathrm{H}$ & $\mathrm{H}$ & $\mathrm{CH}_{3}$ & $\mathrm{Cl}$ & - & - & active & active \\
\hline 17 & E & $\mathrm{CH}_{3} \mathrm{O}$ & $\mathrm{CH}_{3} \mathrm{O}$ & $\mathrm{CH}_{3}$ & $\mathrm{CH}_{3}$ & - & - & inactive & active \\
\hline 18 & E & $\mathrm{CH}_{3} \mathrm{O}$ & $\mathrm{CH}_{3} \mathrm{O}$ & $\mathrm{CH}_{3}$ & $\mathrm{Cl}$ & - & - & inactive & active \\
\hline 19 & $\mathrm{~F}$ & $\mathrm{H}$ & $\mathrm{H}$ & $\mathrm{CH}_{3}$ & $\mathrm{Cl}$ & - & - & inactive & inactive \\
\hline 20 & A & $\mathrm{H}$ & $\mathrm{H}$ & $\mathrm{H}$ & $\mathrm{H}$ & $\mathrm{Cl}$ & $\mathrm{H}$ & training & training \\
\hline
\end{tabular}

$\beta$-ketosulfone derivatives are closely related to natural $8,4^{\prime}$-oxyneolignans, which are of interest because of their moderate antileishmaniasis activity against both intracellular amastigotes of $L$. donovani and $L$. amazonensis. ${ }^{14}$ Insight into the biological and physicochemical functions of complex neolignans at the molecular level requires a precise understanding of their three-dimensional structures. Figure 3 shows the basic skeletons of the twenty compounds studied and Table 1 lists their classes and biological response. Two of these neolignan derivatives, $\beta$-ketosulfide 12 and $\beta$-ketoether $\mathbf{2 0}$ were synthesized from condensation reactions among $\alpha$-bromoketone and thiophenol or phenol derivatives, respectively, with their structures elucidated by X-ray crystal diffraction. The synthesis of $\mathbf{1 2}$ was mentioned previously, ${ }^{15}$ but the crystal data and structural features were not published. Here, we report the synthesis and the X-ray crystallographic studies of $\mathbf{1 2}$ and $\mathbf{2 0}$ with a comparison of their three-dimensional structures.

\section{Synthesis}

In the present study, 2-[(4-chlorophenyl)thio]-1-(3,4dimethoxyphenyl)propan-1-one (12) was prepared by reaction of $\alpha$-bromo-3,4-dimethoxypropiophenone and<smiles>[R7]c1ccc(SC([R])C(=O)c2ccc([R2])c([R])c2)cc1</smiles><smiles>[R]c1ccc(S(=O)(=O)C([R])C(=O)c2ccc([R])c([R])c2)cc1</smiles><smiles>[R2]c1ccc(SC([R])C(O)c2ccc([R])c([R])c2)cc1</smiles><smiles>[R]C(Sc1ccc(Cl)cc1)C(OC(C)=O)c1ccccc1</smiles>

D

$$
\text { E }
$$

Figure 3. Strucutal skeleton and numbering of twenty neolignan derivatives. 
4-chlorothiophenol in anhydrous ethyl methyl ketone, in accordance with the method described in the literature. ${ }^{14,15}$ The $\beta$-ketoether 2-(4-chlorophenyl)-1-phenylethanone (20) was prepared by reacting equimolecular amounts of $\alpha$-bromoacetophenone and 4-chlorophenol, in basic solution. The synthetic route of compounds is outlined in Figure 4. The structures of compounds were confirmed through analytical and spectral data $\left({ }^{1} \mathrm{H}\right.$ NMR, IR, and MS).

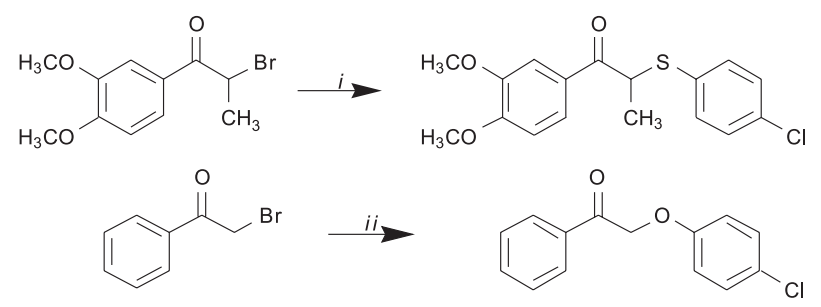

Figure 4. Synthesis of $\beta$-ketosulfide 12 and $\beta$-ketoether 20. Reagents and conditions: (i) 4-chlorothiophenol, $\mathrm{K}_{2} \mathrm{CO}_{3}$, butanone, $\Delta$; (ii) 4-chlorophenol, $\mathrm{K}_{2} \mathrm{CO}_{3}$, butanone, $\Delta$.

\section{2-[(4-Chlorophenyl)thio]-1-(3,4-dimethoxyphenyl)propan- 1-one (12)}

The 2-[(4-chlorophenyl)thio]-1-(3,4-dimethoxyphenyl) propan-1-one (12) was obtained from a solution of $1.36 \mathrm{~g}$ (9.43 mmol) of 4-chlorothiophenol and $2.27 \mathrm{~g}$ (16.48 mmol) of anhydrous $\mathrm{K}_{2} \mathrm{CO}_{3}$ in $45 \mathrm{~mL}$ of anhydrous ethyl methyl ketone was stirred for $10 \mathrm{~min}$ at room temperature. After this period, a solution of $2.50 \mathrm{~g}(9.16 \mathrm{mmol})$ of the $\alpha$-bromo-3,4-dimethoxypropiophenone in $20 \mathrm{~mL}$ of anhydrous ethyl methyl ketone was added dropwise and the mixture was stirred and refluxed for $8 \mathrm{~h}$. The solution was cooled at room temperature, filtered, and the residue washed with $\mathrm{CH}_{2} \mathrm{Cl}_{2}$. The solution was concentrated in vacuum (to eliminate the ethyl methyl ketone), diluted with $\mathrm{H}_{2} \mathrm{O}$, and extracted thoroughly with $\mathrm{CH}_{2} \mathrm{Cl}_{2}(3 \times)$. Organic extracts were combined, washed with water, $5 \% \mathrm{NaHCO}_{3}$ solution, $\mathrm{NaCl}$ saturated solution, dried over $\mathrm{Na}_{2} \mathrm{SO}_{4}$ and then filtered and concentrated in vacuum. The residue was purified by crystallization with $\mathrm{MeOH}$ giving 12 (2.52 g) as colorless crystals, mp $92-93{ }^{\circ} \mathrm{C}$ in $81.7 \%$ yield. The spectrometric data is in concordance with the literature. ${ }^{14,15}$

\section{2-(4-Chlorophenyl)-1-phenylethanone (20)}

The 2-(4-chlorophenyl)-1-phenylethanone (20) was obtained from a solution of $0.66 \mathrm{~g}(5.12 \mathrm{mmol})$ of 4-chlorophenol and $1.25 \mathrm{~g}$ (9.04 mmol) of anhydrous $\mathrm{K}_{2} \mathrm{CO}_{3}$ in $20 \mathrm{~mL}$ of anhydrous ethyl methyl ketone was stirred for $10 \mathrm{~min}$ at room temperature. After this period, a solution of $1.0 \mathrm{~g}$ ( $5.02 \mathrm{mmol})$ of the $\alpha$-bromo-acetophenone in $7.5 \mathrm{~mL}$ of anhydrous ethyl methyl ketone was added dropwise and the mixture was stirred and refluxed for $1.5 \mathrm{~h}$. The solution was cooled at room temperature, filtered, and the residue washed with $\mathrm{CH}_{2} \mathrm{Cl}_{2}$. The solution was concentrated in vacuum (to eliminate the ethyl methyl ketone), diluted with $\mathrm{H}_{2} \mathrm{O}$, and extracted thoroughly with $\mathrm{CH}_{2} \mathrm{Cl}_{2}(3 \times)$. Organic extracts were combined, washed with water, $5 \% \mathrm{NaHCO}_{3}$ solution, $\mathrm{NaCl}$ saturated solution, dried over $\mathrm{Na}_{2} \mathrm{SO}_{4}$ and then filtered and concentrated in vacuum. The residue was purified by crystallization with $\mathrm{MeOH}$ giving 20 (1.18 g) as colorless crystals, mp $99-100{ }^{\circ} \mathrm{C}$ in $95 \%$ yield. IR $v_{\max } / \mathrm{cm}^{-1} 2910,1700$ $(\mathrm{C}=\mathrm{O}), 1600,1580,1490,1440,1230(\mathrm{KBr}) ;{ }^{1} \mathrm{H}$ NMR $(100$ $\left.\mathrm{MHz}, \mathrm{CDCl}_{3}\right) \delta 5.22(2 \mathrm{H}, \mathrm{s}, 2 \mathrm{H}-8), 6.90(2 \mathrm{H}, \delta, J 7.0 \mathrm{~Hz}$, H-3'/H-5'), 7.20 (2H, d, J 7.0 Hz, H-2'/H-6'), 7.35-7.60 (3H, $\mathrm{m}, \mathrm{H}-3, \mathrm{H}-4$ and H-5), 7.95 (2H, dd, $J 6.8 \mathrm{~Hz}$ and $J 1.5 \mathrm{~Hz}$, $\mathrm{H}-2 / \mathrm{H}-6$ ); EIMS (probe) $70 \mathrm{eV}, \mathrm{m} / \mathrm{z}$ (rel. int.) $246[\mathrm{M}]^{+}(40)$, $139\left[\mathrm{C}_{7} \mathrm{H}_{5} \mathrm{O}\right]^{+}(100)$.

\section{Crystallographic data}

Suitable colorless single crystals of the neolignan derivatives $\mathbf{1 2}$ and 20, with approximate dimensions $0.05 \times 0.05 \times 0.10$ and $0.05 \times 0.10 \times 0.10 \mathrm{~mm}$, respectively, were selected and the diffraction data were collected using an Enraf-Nonius CAD4 diffractometer with graphite monochromated $\mathrm{K}_{\alpha}$ Mo radiation $(\lambda=0.71073 \AA)$, in the $\omega-2 \theta$ scan mode, at room temperature. The unit cell parameters were determined using 25 automatically centered reflections. Intensities of the reflections were corrected by absorption factors $\left[\mu\left(\mathrm{MoK}_{\alpha}\right)=0.308\right.$ and 0.367, for compounds $\mathbf{1 2}$ and 20, respectively] using the PSISCAN method. ${ }^{46}$ Information concerning to the crystallographic data collection and refinement of the structures are given in Table 2. The structures were solved by SIR- $92^{47}$ and refined by full matrix least squares and difference Fourier synthesis by SHELXL-97, ${ }^{48}$ using the WinGX software package. ${ }^{49}$ All non-hydrogen atoms were refined anisotropically. The hydrogen atoms were located in their ideal positions and not refined. The structural analysis was performed by PLATON system. ${ }^{50}$ The graphic representations of the molecules were made using ORTEP3 for Windows. ${ }^{51}$ The crystal data are deposited at Cambridge Crystallographic Data Centre, CCDC 703864 and 703867 , for compound $\mathbf{1 2}$ and $\mathbf{2 0}$, respectively.

\section{Computational methods}

The molecular geometries obtained from X-ray diffraction data of $\mathbf{1 2}$ and $\mathbf{2 0}$ were used here as a starting point for our calculations of the remaining molecules, just changing the substituent. All compounds were optimized using the B3LYP hybrid functional, ${ }^{52,53}$ together with the 
Table 2. Crystallographic data for compounds $\mathbf{1 2}$ and $\mathbf{2 0}$

\begin{tabular}{|c|c|c|}
\hline Formula & $\mathrm{C}_{17} \mathrm{H}_{17} \mathrm{O}_{3} \mathrm{ClS}(\mathbf{1 2})$ & $\mathrm{C}_{14} \mathrm{H}_{11} \mathrm{ClO}_{2}(\mathbf{2 0})$ \\
\hline Formula weight & 336.83 & 246.68 \\
\hline Crystal system & monoclinic & monoclinic \\
\hline Space group & $\mathrm{P} 2{ }_{1}$ & $\mathrm{P} 2 / \mathrm{c}$ \\
\hline $\mathrm{a}(\AA)$ & $8.765(1)$ & $5.840(1)$ \\
\hline $\mathrm{b}(\AA)$ & $7.975(1)$ & $7.374(2)$ \\
\hline c $(\AA)$ & $11.8155(1)$ & 27.492(8) \\
\hline$\beta\left({ }^{\circ}\right)$ & 93.663(7) & $90.26(2)$ \\
\hline $\mathrm{Z}$ & 2 & 4 \\
\hline$V\left(\AA^{3}\right)$ & $824.3(2)$ & $1184.5(5)$ \\
\hline Crystal size (mm) & $0.05 \times 0.05 \times 0.10$ & $0.05 \times 0.10 \times 0.10$ \\
\hline Crystal color & colorless & colorless \\
\hline$\mu\left(\mathrm{MoK}_{\alpha}\right)\left(\mathrm{mm}^{-1}\right)$ & 0.367 & 0.308 \\
\hline Reflections: total; unique; Rint & $1880 ; 1791 ; 0.035$ & $2654 ; 2411 ; 0.027$ \\
\hline Observed Reflections $(\mathrm{I}>2 \sigma(\mathrm{I}))$ & 1598 & 1422 \\
\hline $\mathrm{R} ; \mathrm{wR} 2$ & $0.0322 ; 0.0920$ & $0.0552 ; 0.1796$ \\
\hline GOF; Npar & $1.05 ; 202$ & $1.03 ; 154$ \\
\hline Min. and max. resd. dens. $\left[\mathrm{e} / \AA^{3}\right]$ & $-0.20,0.17$ & $-0.22,0.39$ \\
\hline W where $\mathrm{P}=\left(\mathrm{Fo}^{2}+2 \mathrm{Fc}^{2}\right) / 3$ & $1 /\left[\backslash \sigma^{2}\left(\mathrm{Fo}^{2}\right)+(0.056 \mathrm{P})^{2}+1.10 \mathrm{P}\right]$ & $1 /\left[\backslash \sigma^{2}\left(\mathrm{Fo}^{2}\right)+(0.086 \mathrm{P})^{2}+0.60 \mathrm{P}\right]$ \\
\hline
\end{tabular}

$6-311++\mathrm{G}(d, p)$ basis sets in the Gaussian 03 molecular package. ${ }^{54}$ Vibrational analysis was carried out for the complete equilibrium geometry obtained by the procedure in the Gaussian 03 package at the DFT level with the $\mathrm{B} 3 \mathrm{LYP} / 6-311++\mathrm{G}(d, p)$ level in the gas phase, ensuring that each gradient optimization located was indeed a true minimum energy structure (no imaginary frequencies). In addition, the conformational analysis were carried out to confirm the minimum energy structure to molecules $\mathbf{1 2}$ and 20, by carrying out a series of partial optimizations constraining the concerned dihedral angle step by step within the appropriate range, with a step size of $5^{\circ}$, these calculations were carried out using the B3LYP/6-31G* basis set, the dihedral angles analyzed were $\mathrm{C} 1-\mathrm{C} 7-\mathrm{C} 8-\mathrm{O}$ and $\mathrm{C} 4{ }^{\prime}-\mathrm{O}-\mathrm{C} 8-\mathrm{C} 7$ for molecule $\mathbf{1 2}$ and $\mathrm{C} 1-\mathrm{C} 7-\mathrm{C} 8-\mathrm{S}$ and $\mathrm{C} 4{ }^{\prime}-\mathrm{S}-\mathrm{C} 8-\mathrm{C} 7$ for molecule 20. Previous studies about conformational preferences in solid state (crystal) and in solution has been published ${ }^{5-57}$ for a large number of compounds analogues of the compounds $\mathbf{1 2}$ and $\mathbf{2 0}$, studied in the present paper. The geometrical structures of the radicals studied were optimized independently from the neutral molecules prior to the calculations of energies, treated as open shell systems DFT/UB3LYP. Thus, the more relevance electronic descriptors to antileishmaniasis activities were calculated such as: eletrostatic potential atomic charges $\left(\mathrm{Q}_{\mathrm{N}}\right.$ - net atomic charge on atom $\left.\mathrm{N}\right)$, occupied and unoccupied molecular orbital energies $\left(\varepsilon_{\text {номо }}\right.$ and $\varepsilon_{\text {LUMO }}$ ), electronegativity $(\chi)$, hardness $(\eta)$, softness
$(1 / \eta)$, chemist potential $(\mu)$, electrophilic index $(\omega)$ and electronic affinity (EA) were calculated with the DFT/ B3LYP level, together with the $6-311++\mathrm{G}(d, p)$ basis sets.

The $\chi$ was calculated as the sum mean between the energies of HOMO and LUMO $\left(\chi=-\left(\varepsilon_{\text {номо }}+\varepsilon_{\text {LUMO }}\right) / 2\right) .^{58}$ The $\eta$ is simply the energy difference between LUMO and HOMO energies, while the $1 / \eta$ is the inverse of the hardness. ${ }^{59}$ The $\mu$ is simply Koopmans' approximation. ${ }^{60}$ From equation $\omega=\mu^{2} / 2 \eta$ we obtained the electrophilic index. ${ }^{58}$ The IP was calculated as the energy differences between a radical cation $(\mathrm{Ec})$ and the respective neutral molecule (En); IP = Ec - En. ${ }^{61}$ The volume (Vol), molecular refractivity (MR), polarizability (Pol), partition coefficient $(\mathrm{C} \log \mathrm{P})$ and hydration energy (HE) were obtained by using the Hyperchem 7.5 molecular package. ${ }^{62}$ The transport of a compound through membranes can be modeled by molecular hydrophobicity, which can be described by octanol/water partition coefficients $(\mathrm{ClogP})$. The value of this property was obtained by using the Chem-3D molecular package. ${ }^{63}$ Table 3 shows almost molecular descriptors.

The atomic charges were obtained by employing the electrostatic potential method, which was used because the charges derived from the electrostatic potential method are physically more satisfactory than Mulliken's charges, especially when related to biological activity. The choice of the best descriptors to correlate with the biological activities was performed using stepwise discriminant analysis (SDA) built in the Minitab 14 statistical software. ${ }^{64}$ 
Table 3. The eight most important descriptors that classified the twenty neolignans used in the SDA study

\begin{tabular}{|c|c|c|c|c|c|c|c|c|}
\hline Derivatives & EA (eV) & $\mathrm{Clog} \mathrm{P}$ & Q1 & Q2 & Q6 & $(\mathrm{O}$ or $\mathrm{S})$ & Q1' & Q5' \\
\hline 1 & 0.38 & 3.02 & -0.02 & -0.16 & -0.01 & -0.54 & 0.10 & -0.27 \\
\hline 2 & 0.78 & 4.00 & -0.02 & -0.18 & -0.05 & -0.44 & 0.12 & 0.07 \\
\hline 3 & 0.35 & 3.77 & -0.14 & -0.17 & -0.08 & -0.52 & -0.16 & -0.31 \\
\hline 4 & 0.26 & 2.61 & -0.12 & -0.14 & -0.09 & -0.39 & 0.11 & 0.40 \\
\hline 5 & 0.25 & 4.22 & -0.18 & -0.13 & -0.14 & -0.50 & -0.27 & 0.34 \\
\hline 6 & 0.62 & 4.43 & -0.04 & -0.12 & -0.02 & -0.28 & -0.16 & -0.18 \\
\hline 7 & 0.86 & 5.22 & -0.06 & -0.15 & -0.02 & -0.28 & -0.16 & -0.21 \\
\hline 8 & 0.48 & 3.97 & -0.04 & -0.10 & -0.03 & -0.31 & 0.09 & -0.04 \\
\hline 9 & 0.45 & 2.74 & -0.05 & -0.19 & 0.01 & -0.34 & -0.81 & -0.09 \\
\hline 10 & 0.61 & 4.74 & -0.08 & -0.07 & 0.01 & -0.31 & -0.15 & -0.07 \\
\hline 11 & 0.28 & 4.36 & -0.15 & -0.11 & -0.08 & -0.31 & -0.17 & -0.03 \\
\hline 12 & 0.45 & 4.63 & -0.17 & -0.09 & -0.07 & -0.31 & -0.14 & -0.07 \\
\hline 13 & 0.87 & 3.10 & -0.08 & -0.16 & -0.04 & -0.02 & -0.12 & -0.07 \\
\hline 14 & 1.01 & 3.05 & -0.04 & -0.10 & -0.03 & 0.99 & -0.12 & -0.04 \\
\hline 15 & 0.62 & 2.61 & -0.12 & -0.16 & -0.16 & 0.97 & -0.23 & 0.00 \\
\hline 16 & -0.01 & 4.37 & 0.08 & -0.20 & -0.05 & -0.41 & -0.14 & -0.16 \\
\hline 17 & -0.19 & 3.76 & 0.04 & -0.18 & -0.23 & -0.37 & -0.22 & -0.10 \\
\hline 18 & 0.01 & 4.03 & -0.10 & -0.20 & -0.08 & -0.44 & -0.14 & -0.16 \\
\hline 19 & -0.09 & 5.23 & 0.05 & 0.07 & -0.21 & -0.25 & -0.14 & -0.22 \\
\hline 20 & 0.41 & 3.87 & -0.09 & -0.13 & 0.02 & -0.54 & -0.16 & -0.33 \\
\hline
\end{tabular}

The molecular electrostatic potential (MEP) surface was generated using the geometry optimized in B3LYP/6$311++\mathrm{G}(d, p)$ and an isodensity surface of 0.002 a.u. On the MEP surface, regions indicating the excess of negative potential correspond to excess negative charges, i.e., attraction of the positively charged probe. The MEP surface was calculated and analyzed visually using the PC Spartan PRO molecular package. ${ }^{65}$

\section{Results and Discussion}

\section{Synthesis}

The molecules $\mathbf{1 2}$ and $\mathbf{2 0}$ (Figure 4) were synthesized through procedures described in the literature ${ }^{14,15}$ using the condensation reaction of $\alpha$-bromoketones with a phenol or thiophenol derivatives, in basic medium. Compound $\mathbf{1 2}$ was synthesized from the condensation reaction of $\alpha$-bromo3,4-dimethoxypropiophenone and 4-chlorothiophenol in anhydrous ethyl methyl ketone, in $81.7 \%$ yield. The spectroscopic data of compound $\mathbf{1 2}$ is in concordance with the literature. ${ }^{14,15}$ Compound $\mathbf{2 0}$ was synthesized in the same conditions, from reaction of $\alpha$-bromoacetophenone and 4-chlorophenol, in 95\% yield. Spectroscopic data and physical properties of compound $\mathbf{2 0}$ are described for the first time in this paper. The compounds were purified by PTLC and purity done by GC-MS. Compound 20 was isolated as a colorless crystals and molecular formula was determined by elemental analysis and $\mathrm{MS} \mathrm{M}^{+} \mathrm{C}_{14} \mathrm{H}_{11} \mathrm{O}_{2} \mathrm{Cl}$ [246 (40\%)]. Its ${ }^{1} \mathrm{H}$ NMR spectrum showed typical signals of an aromatic compound. The singlet signal at $\delta 5.20 \mathrm{ppm}$ was assigned to the two $\mathrm{H}-8$ protons. The two doublets at $\delta$ 6.90 and $7.20 \mathrm{ppm}$ with orto coupling $(J 7.0 \mathrm{~Hz})$ belong to the pairs $\mathrm{H}-3^{\prime} / \mathrm{H}-5^{\prime}$ and $\mathrm{H}-2^{\prime} / \mathrm{H}-6^{\prime}$ protons of the aromatic ring-B, respectively. Multiplet signals at $\delta 7.35-7.60 \mathrm{ppm}$ are due to $\mathrm{H}-3, \mathrm{H}-4$ and $\mathrm{H}-5$ protons of the aromatic ring- $\mathrm{A}$ and the signal at $\delta 7.95 \mathrm{ppm}(\mathrm{dd}, J 6.8 \mathrm{~Hz}$ and $J 1.5 \mathrm{~Hz}$ ) was assigned to the H-2 and H-6 protons.

\section{$X$-ray crystallography}

The ORTEP representations of the molecular structure of 2-[(4-chlorophenyl)thio]-1-(3,4-dimethoxyphenyl)propan1-one (12) and 2-(4-chlorophenyl)-1-phenylethanone (20) with the atom labelling scheme are depicted in Figures 1 and 2 , respectively, using thermal vibration factors with $50 \%$ of probability.

As shown in the crystal representation (see Figures 1 and 2), both compounds have a $\mathrm{Cl}$ atom in position $4^{\prime}$ (ring B), whereas compound $\mathbf{1 2}$ has also an $-\mathrm{OCH}_{3}$ group in positions 
Table 4. Crystal X-ray and B3LYP/6-311++G(d,p) selected bond lengths ( $\mathrm{A})$ for compounds 12 and 20

\begin{tabular}{|c|c|c|c|c|c|}
\hline \multirow[t]{2}{*}{ Bond distances } & \multicolumn{3}{|c|}{ Compound 12} & \multicolumn{2}{|c|}{ Compound 20} \\
\hline & Crystal X-ray ${ }^{a}$ & B3LYP/6-311++G $(d, p)$ & Bond distances & Crystal X-ray ${ }^{a}$ & B3LYP/6-311++G $(d, p)$ \\
\hline $\mathrm{S}-\mathrm{C} 8$ & $1.838(3)$ & 1.875 & $\mathrm{O} 2-\mathrm{C} 2$ & $1.418(4)$ & 1.418 \\
\hline S-C9 & $1.776(3)$ & 1.795 & $\mathrm{O} 2-\mathrm{C} 9$ & $1.369(4)$ & 1.369 \\
\hline $\mathrm{O} 1-\mathrm{C} 1$ & $1.217(3)$ & 1.221 & $\mathrm{O} 1-\mathrm{C} 1$ & $1.212(4)$ & 1.212 \\
\hline $\mathrm{O} 2-\mathrm{C} 4$ & $1.361(3)$ & 1.358 & $\mathrm{C} 1-\mathrm{C} 2$ & $1.506(4)$ & 1.506 \\
\hline $\mathrm{O} 3-\mathrm{C} 5$ & $1.352(3)$ & 1.352 & $\mathrm{C} 1-\mathrm{C} 3$ & $1.481(4)$ & 1.481 \\
\hline $\mathrm{O} 2-\mathrm{C} 15$ & $1.410(4)$ & 1.423 & $\mathrm{C} 3-\mathrm{C} 4$ & $1.393(4)$ & 1.393 \\
\hline $\mathrm{O} 3-\mathrm{C} 16$ & $1.435(4)$ & 1.423 & $\mathrm{C} 3-\mathrm{C} 8$ & $1.394(4)$ & 1.394 \\
\hline $\mathrm{C} 1-\mathrm{C} 2$ & $1.484(3)$ & 1.492 & $\mathrm{C} 4-\mathrm{C} 5$ & $1.377(5)$ & 1.376 \\
\hline $\mathrm{C} 1-\mathrm{C} 8$ & $1.518(4)$ & 1.530 & C5-C6 & $1.382(5)$ & 1.383 \\
\hline $\mathrm{C} 2-\mathrm{C} 3$ & $1.402(4)$ & 1.410 & $\mathrm{C} 6-\mathrm{C} 7$ & $1.387(5)$ & 1.387 \\
\hline $\mathrm{C} 2-\mathrm{C} 7$ & $1.386(4)$ & 1.393 & $\mathrm{C} 7-\mathrm{C} 8$ & $1.384(5)$ & 1.384 \\
\hline $\mathrm{C} 3-\mathrm{C} 4$ & $1.366(4)$ & 1.383 & C9-C10 & $1.383(4)$ & 1.382 \\
\hline $\mathrm{C} 4-\mathrm{C} 5$ & $1.419(4)$ & 1.421 & C9-C14 & $1.395(4)$ & 1.395 \\
\hline C5-C6 & $1.378(4)$ & 1.393 & $\mathrm{C} 10-\mathrm{C} 11$ & $1.376(5)$ & 1.376 \\
\hline C6-C7 & $1.386(4)$ & 1.396 & $\mathrm{C} 11-\mathrm{C} 12$ & $1.379(4)$ & 1.380 \\
\hline $\mathrm{C} 8-\mathrm{C} 17$ & $1.511(4)$ & 1.523 & C12-C13 & $1.374(5)$ & 1.374 \\
\hline C9-C10 & $1.390(4)$ & 1.399 & C13-C14 & $1.385(5)$ & 1.385 \\
\hline C9-C14 & $1.388(4)$ & 1.399 & $\mathrm{Cl}-\mathrm{C} 12$ & $1.742(3)$ & 1.743 \\
\hline $\mathrm{C} 10-\mathrm{C} 11$ & $1.375(5)$ & 1.393 & & & \\
\hline $\mathrm{C} 11-\mathrm{C} 12$ & $1.374(5)$ & 1.391 & & & \\
\hline $\mathrm{C} 12-\mathrm{C} 13$ & $1.384(5)$ & 1.391 & & & \\
\hline C13-C14 & $1.379(5)$ & 1.392 & & & \\
\hline $\mathrm{Cl}-\mathrm{C} 12$ & $1.739(3)$ & 1.758 & & & \\
\hline
\end{tabular}

${ }^{a}$ Estimated standard deviation are given in parentheses.

3 and 4 (ring A). The bond distances for the single bonds $\mathrm{C}-\mathrm{O}$ are 1.418(4) and 1.369(4) $\AA$ for compound $\mathbf{2 0}$, and the $\mathrm{C}-\mathrm{S}$, as expected, are 1.838(3) and 1.776(3) $\AA$ for 12. No significant differences were found in the bond distances and angles of the two molecules, the others bond lengths $\mathrm{C}=\mathrm{O}$, $\mathrm{C}-\mathrm{Cl}$ and $\mathrm{C}-\mathrm{C}$ are in the expected ranges. The distances and angles parameters are listed in Table 4 and 5, respectively.

The most relevant structural difference is that the structure of $\mathbf{2 0}$ is almost planar, with the dihedral angle between the two benzene planes of $2.8(1)^{\circ}$, while the structure of $\mathbf{1 2}$ is itself twisted out of the plane of the aromatic rings, as can be seen from the $\mathrm{C} 1-\mathrm{C} 2-\mathrm{S}-\mathrm{C} 9$ torsion angle of $123.3(5)^{\circ}$. The dihedral angle between the rings $\mathrm{A}$ and $\mathrm{B}$ is $34.4(1)^{\circ}$, which presumably reflects some flexibility of the molecule, enabling it to rotate and deform in order to minimize any unfavorable intramolecular interactions due to the presence of the methyl group. Also, in compound $\mathbf{1 2}$ the keto atom is more coplanar in relation to the ring A. The keto atom O1 is 0.254(3) $\AA$ out of the least-squares plane of the ring
A. In compound 20 the same keto atom is 0.464(2) A out of the plane A. The three-dimensional structure of the compound $\mathbf{1 2}$ and $\mathbf{2 0}$ and the non-covalent interactions formed in their crystal structure along the b-axis are shown in Figure 5 and 6.

In the crystal packing of $\mathbf{1 2}$, the oxygen from the methoxy group participates in two non conventional $\mathrm{C}-\mathrm{H} \cdots \mathrm{O}$ hydrogen bonds. The molecules of $\mathbf{1 2}$ are joined via intermolecular hydrogen bonds (C10 ...03 3.491(4) $\AA$, $\mathrm{H} 10-\mathrm{O} 32.57 \AA, 170.0^{\circ}$ and $\mathrm{C} 16 \cdots \mathrm{O} 23.323(5) \AA$, $\mathrm{H} 16 \mathrm{C}-\mathrm{O} 22.60 \AA, 132.0^{\circ}$ ) giving rise to the formation of the zig-zag supramolecular chain, as shown in the Figure 5. The crystal packing of $\mathbf{2 0}$ also shows the existence of an intermolecular $\mathrm{C}-\mathrm{H} \cdots \mathrm{O}$

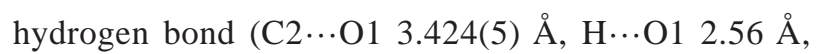
$\left.\mathrm{C} 2-\mathrm{H} 2 \mathrm{~B} \cdots \mathrm{O} 11^{\circ}\right)$. As can be observed in Figure 6, this hydrogen bond are responsible for the self-assembly into one-dimensional chain, formed by the interaction at the end of the neighboring molecules while in the $\mathbf{1 2}$ it was formed in the middle of adjacent molecules. 
Table 5. Crystal X-ray and B3LYP/6-311++G $(d, p)$ selected angles lengths $\left(^{\circ}\right)$ for compounds $\mathbf{1 2}$ and $\mathbf{2 0}$

\begin{tabular}{|c|c|c|c|c|c|}
\hline \multirow[t]{2}{*}{ Angles lengths } & \multicolumn{3}{|c|}{ Compound 12} & \multicolumn{2}{|c|}{ Compound 20} \\
\hline & Crystal X-ray ${ }^{a}$ & B3LYP/6-311++G $(d, p)$ & Angles lengths & Crystal X-ray $^{a}$ & B3LYP/6-311++G $(d, p)$ \\
\hline $\mathrm{C} 8-\mathrm{S}-\mathrm{C} 9$ & $103.8(1)$ & 103.8 & $\mathrm{C} 2-\mathrm{O} 2-\mathrm{C} 9$ & $118.2(2)$ & 118.2 \\
\hline $\mathrm{C} 4-\mathrm{O} 2-\mathrm{C} 15$ & 117.7(2) & 118.1 & $\mathrm{O} 1-\mathrm{C} 1-\mathrm{C} 2$ & $121.2(3)$ & 121.3 \\
\hline $\mathrm{C} 5-\mathrm{O} 3-\mathrm{C} 16$ & 117.2(3) & 118.7 & $\mathrm{O} 1-\mathrm{C} 1-\mathrm{C} 3$ & $121.6(3)$ & 121.5 \\
\hline $\mathrm{O} 1-\mathrm{C} 1-\mathrm{C} 2$ & $121.7(2)$ & 120.8 & $\mathrm{C} 2-\mathrm{C} 1-\mathrm{C} 3$ & $117.2(3)$ & 117.2 \\
\hline $\mathrm{O} 1-\mathrm{C} 1-\mathrm{C} 8$ & $120.3(2)$ & 119.1 & $\mathrm{O} 2-\mathrm{C} 2-\mathrm{C} 1$ & $108.5(2)$ & 108.5 \\
\hline $\mathrm{C} 2-\mathrm{C} 1-\mathrm{C} 8$ & $117.8(2)$ & 120.1 & $\mathrm{C} 1-\mathrm{C} 3-\mathrm{C} 4$ & $118.5(3)$ & 118.5 \\
\hline $\mathrm{C} 1-\mathrm{C} 2-\mathrm{C} 3$ & $119.5(2)$ & 117.1 & $\mathrm{C} 1-\mathrm{C} 3-\mathrm{C} 8$ & $122.6(3)$ & 122.6 \\
\hline $\mathrm{C} 1-\mathrm{C} 2-\mathrm{C} 7$ & $122.0(2)$ & 124.2 & $\mathrm{C} 4-\mathrm{C} 3-\mathrm{C} 8$ & $118.9(3)$ & 118.9 \\
\hline $\mathrm{C} 3-\mathrm{C} 2-\mathrm{C} 7$ & $118.5(2)$ & 118.8 & $\mathrm{C} 3-\mathrm{C} 4-\mathrm{C} 5$ & 121.1(3) & 121.1 \\
\hline $\mathrm{C} 2-\mathrm{C} 3-\mathrm{C} 4$ & $121.1(2)$ & 121.4 & $\mathrm{C} 4-\mathrm{C} 5-\mathrm{C} 6$ & $119.9(3)$ & 119.9 \\
\hline $\mathrm{O} 2-\mathrm{C} 4-\mathrm{C} 3$ & $125.9(2)$ & 125.1 & $\mathrm{C} 5-\mathrm{C} 6-\mathrm{C} 7$ & 119.7(3) & 119.7 \\
\hline $\mathrm{O} 2-\mathrm{C} 4-\mathrm{C} 5$ & $114.2(2)$ & 115.6 & $\mathrm{C} 6-\mathrm{C} 7-\mathrm{C} 8$ & $120.6(3)$ & 120.6 \\
\hline $\mathrm{C} 3-\mathrm{C} 4-\mathrm{C} 5$ & $119.9(2)$ & 119.4 & $\mathrm{C} 3-\mathrm{C} 8-\mathrm{C} 7$ & $119.8(3)$ & 119.8 \\
\hline $\mathrm{O} 3-\mathrm{C} 5-\mathrm{C} 4$ & $115.6(3)$ & 115.8 & $\mathrm{O} 2-\mathrm{C} 9-\mathrm{C} 10$ & $115.0(3)$ & 115.0 \\
\hline $\mathrm{O} 3-\mathrm{C} 5-\mathrm{C} 6$ & $125.3(2)$ & 124.9 & $\mathrm{O} 2-\mathrm{C} 9-\mathrm{C} 14$ & $124.7(3)$ & 124.7 \\
\hline C4-C5-C6 & $119.1(2)$ & 119.3 & C10-C9-C14 & $120.3(3)$ & 120.3 \\
\hline C5-C6-C7 & $120.4(3)$ & 120.7 & C9-C10-C11 & $120.4(3)$ & 120.3 \\
\hline $\mathrm{C} 2-\mathrm{C} 7-\mathrm{C} 6$ & $121.0(3)$ & 120.5 & $\mathrm{C} 10-\mathrm{C} 11-\mathrm{C} 12$ & 119.2(3) & 119.1 \\
\hline $\mathrm{S}-\mathrm{C} 8-\mathrm{C} 1$ & $107.4(2)$ & 109.1 & $\mathrm{Cl}-\mathrm{C} 12-\mathrm{C} 11$ & 119.1(3) & 119.1 \\
\hline $\mathrm{S}-\mathrm{C} 8-\mathrm{C} 17$ & $113.5(2)$ & 113.5 & $\mathrm{Cl}-\mathrm{C} 12-\mathrm{C} 13$ & 119.7(2) & 119.6 \\
\hline $\mathrm{C} 1-\mathrm{C} 8-\mathrm{C} 17$ & $113.9(2)$ & 112.6 & $\mathrm{C} 11-\mathrm{C} 12-\mathrm{C} 13$ & 121.2(3) & 121.2 \\
\hline S- C9-C10 & $118.9(2)$ & 120.0 & $\mathrm{C} 12-\mathrm{C} 13-\mathrm{C} 14$ & $120.0(3)$ & 120.0 \\
\hline S-C9-C14 & $121.7(2)$ & 120.6 & C9-C14-C13 & $118.9(3)$ & 118.9 \\
\hline C10-C9-C14 & $119.3(3)$ & 119.2 & & & \\
\hline C9-C10-C11 & $120.3(3)$ & 120.6 & & & \\
\hline C10-C11-12 & 119.7(3) & 119.1 & & & \\
\hline $\mathrm{Cl}-\mathrm{C} 11-\mathrm{C} 12$ & $119.6(3)$ & 119.4 & & & \\
\hline $\mathrm{Cl}-\mathrm{C} 12-\mathrm{C} 13$ & 119.2(2) & 119.4 & & & \\
\hline C11-C12-13 & 121.2(3) & 121.3 & & & \\
\hline C12-C13-14 & $118.8(3)$ & 119.2 & & & \\
\hline C9-C14-C13 & $120.7(3)$ & 120.6 & & & \\
\hline
\end{tabular}

${ }^{\text {a }}$ Estimated standard deviation are given in parentheses.

\section{Theoretical calculations}

The distance lengths and angles for both X-ray and B3LYP/6-311G++ $(d, p)$ optimized structures of 12 and 20 presented in Tables 4 and 5 are normal for this type of compound. The values of $\mathrm{C}-\mathrm{S}$ and $\mathrm{C}-\mathrm{O}$ bond distances calculated for compounds $\mathbf{1 2}$ and $\mathbf{2 0}$ are 1.875 and $1.795 \AA$, and 1.418 and $1.369 \AA$, respectively. The $\mathrm{C} 1-\mathrm{C} 2-\mathrm{S}-\mathrm{C} 9$ torsion angle experimentally observed are $123.3(5)^{\circ}$ and $34.4(1)^{\circ}$, while the values calculated were of $123.3^{\circ}$ and $35.7^{\circ}$ for compounds $\mathbf{1 2}$ and $\mathbf{2 0}$, respectively. These results are in agreement with the experimental values. No significant differences were found between these structures (12 and 20) and the remaining molecules. The harmonic frequency showed that the molecular geometrics obtained by DFT calculations correspond to a local minimum energy structure, no imaginary frequencies. In addition, Table S1 (supplementary material) presents the results to conformational analysis carried out to molecules $\mathbf{1 2}$ and 20. These results indicate that the structures optimized with the $6-311++\mathrm{G}(d, p)$ basis sets using X-ray diffraction data as starting points have the lowest energy, indicating global 


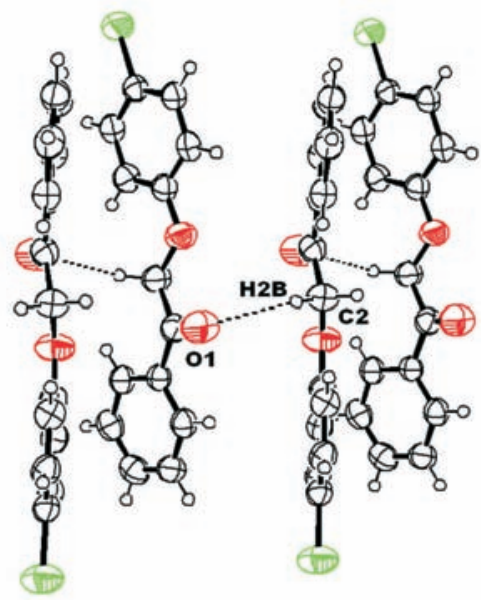

Figure 5. View along the crystallographic b-axis of supramolecular arrangement supported by the intermolecular hydrogen bonds between the adjacent molecules in compound $\mathbf{1 2}$, indicated as dashed lines.

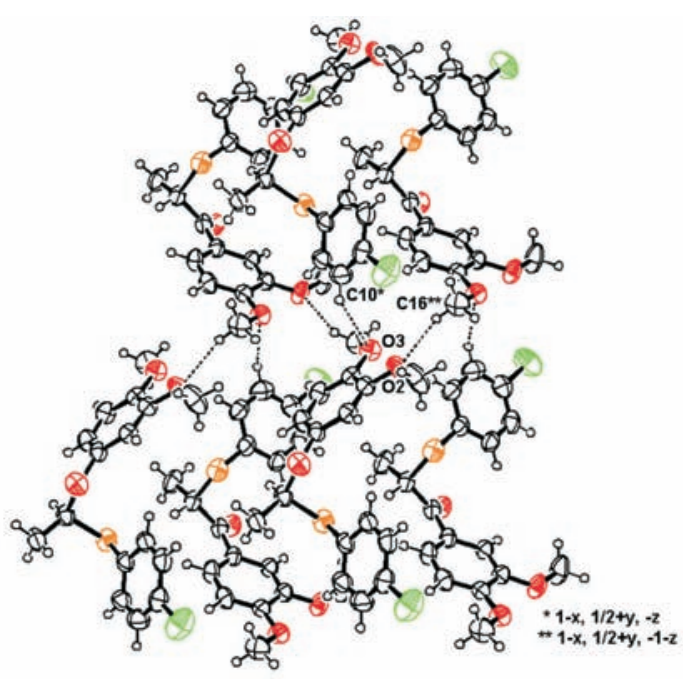

Figure 6. Packing view of supramolecular arrangement formed by the intermolecular hydrogen bonds between the adjacent molecules in compound 20, indicated as dashed lines (online version in color).

minimum energy structures. So the geometries obtained by B3LYP/6-311G++( $d, p)$ level were used to calculate fortyone physicochemical descriptors.

Before applying the SAR analysis to the nineteen compounds under study, each calculated property (variables or descriptors) was auto scaled. In the auto scaling method, each variable is scaled to a mean of zero and a variance of unity. This method is very important because each variable is weighted equally and this provides a measure of the ability of a descriptor to discriminate classes of compounds. With this method, we can compare all variables at the same level although presenting different units.

SAR analysis has been carried out using molecular descriptors that were selected by stepwise discriminant analysis (SDA). The main objective of SDA is to determine discriminant functions using the measured variables that separate the groups as distinctly as possible. In this study, we considered two groups: active and inactive molecules against $L$. donovani and $L$. amazonensis activities. The SDA linear function is based on the Fisher's test (F test) for the significance of the variables. In each step one variable is selected based on its significance and after several steps, the more significant variables are extracted from the whole data set under investigation.

From the twenty-two synthetic analogues of neolignans reported by Aveniente et al. ${ }^{14}$ three of them were not included in the analysis, because they not have experimental values (values reported as "nd" not determined). Therefore, the equations presented in this study were constructed with nineteen molecules compounds 1-19 - that present antileishmaniasis activities (values expressed as percent inhibition of parasite growth at $80 \mu \mathrm{g} \mathrm{mL} \mathrm{m}^{-1}$ concentration). The SDA results will be used for molecule $\mathbf{2 0}$ to verify if this new molecule would be active or inactive. The allocation rule derived from the SDA results, when the antileishmanials activity of a new neolignan compound is investigated, is: (i) initially one calculates, for the new neolignan compound, the values for the more important descriptors obtained with the SDA; (ii) substitute these values in the two discriminant functions obtained in this study; (iii) check out which discriminant function (active or inactive compounds) presents the higher value. The new neolignan compound is active if the higher value is related to the active discriminant function and vice versa.

\section{SDA for the Leishmania donovani activity}

In this analysis, we considered two groups: active molecules (1, 2, 4-6, 8-12 and 16) and inactive molecules $(3,7,13-15,17-19)$ against $L$. donovani. The SDA indicated that the descriptors: electronic affinity (AE), charges on C6, $\mathrm{O}$ or $\mathrm{S}$ and $\mathrm{C} 5$ ' atoms were the most important in order to get the separation of active and inactive compounds. The discriminant functions for $L$. donovani activity obtained with nineteen compounds are given in equation 1 and 2 :

Inactive compounds $=-1.01+1.17(\mathrm{EA})-2.15 \mathrm{Q} 6+0.60$ $(\mathrm{O}$ or $\mathrm{S})-1.46 \mathrm{Q}$ '

Active compounds $=-0.54-0.85(\mathrm{EA})+1.56 \mathrm{Q} 6-0.44$ (O or S) + 1.06 Q5'

Through the discriminant functions above (equation 1 and 2) and the values of each variable for the compounds studied (Table 3); we obtain the classification matrix by using all compounds in the analysis (Table 6). 
Table 6. Classification matrix obtained using the SDA method for L. donovani activity

\begin{tabular}{lccc}
\hline \multirow{2}{*}{ Classified group } & $\%$ & Inactivity & Activity \\
\hline Inactivity & 87.5 & 7 & 1 \\
Activity & 100 & 0 & 11 \\
Total & 94.7 & 7 & 12 \\
\hline
\end{tabular}

The SDA allowed correct classification scores of $100 \%$ (active compounds), $87.5 \%$ (inactive compounds) and $94.7 \%$ (total), resulting in a better performance in the separation of the two groups (Table 6). Derivative $\mathbf{1 8}$ was incorrectly classified in the group of active compounds. Probably this occurred because this compound showed a sulfur bond in position 8 that increases activity if compared to compounds bearing oxygen bond, like previous results shown by Aveniente et al. ${ }^{14}$ Furthermore, the molecule 18 shows a meta chlorine substituents in the $\mathrm{B}$ ring, a methyl substituents in position 7 , and a meta methoxyl substituents in the A ring, similar to molecule $\mathbf{1 3}$ which is active.

In accordance with equation 1 and Table 3, in general, active neolignans against $L$. donovani have more positive charges on atoms 6 and 5' and less positive charges on heteroatom. The charge is electronic descriptor; therefore, we can conclude that electronic effects have a very important role when one is trying to understand the activity of neolignan derivatives. The charges on the atoms $\mathrm{S}$ or $\mathrm{O}$ in compounds $\mathbf{1 4}$ and $\mathbf{1 5}$ have more positive values, because the inductive effect on the $\mathrm{B}$ ring, which have a $\mathrm{Cl}$ substituent in the molecule $\mathbf{1 4}$ and a methyl substituent in the molecule 15 , in general, molecules with more positive values for $\mathrm{S}$ or $\mathrm{O}$ charge are inactives. In Figure 7 is shown the box plot for Q6 (see supplementary material Figure S2 for the Q5' charges).

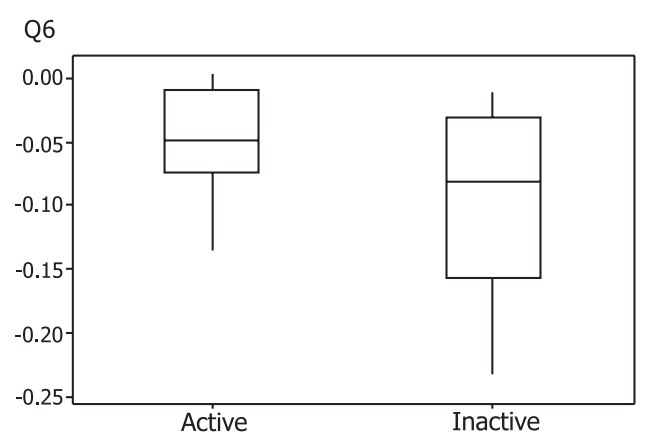

Figure 7. Box plot of L. donovani activity for Q6 considering nineteen neolignan compounds.

In order to verify if a new molecule would be active or inactive against $L$. donovani, we had to apply the results obtained with the discriminant functions for the compound 20. From the results obtained, we can see that this molecule was classified as active, and from it we can conclude that the model obtained with SDA can be applied to new neolignan compounds whose biological activity is unknown.

Recently, we successfully used three-dimensional MEP surfaces to define the most probable sites of protonation of dipyridamole ${ }^{66}$, aparisthman, ${ }^{67}$ cordatin, 8-epicordatin; ${ }^{68}$ on the study of the molecular mechanisms the Diels-Alder reaction ${ }^{69}$ and to get some clues about the transition state of the catalyzed reaction..$^{40}$ The MEP surfaces of compound $\mathbf{1}$ (active) and compound $\mathbf{1 4}$ (inactive) in terms of total electron density show that the lowest electronic potential is in the proximity of oxygen atoms of the carbonyl (O1), and oxygen heteroatom (Figure 8). The large negative potential of oxygen atoms may be regarded to a nucleophilic suction pump, acting as a possible magnet for electrophilic attack of a biological receptor. The surfaces of $\mathbf{1}$ and $\mathbf{1 4}$ are different and compound $\mathbf{1}$ (active) provides a much more intense region of negative electrostatic potential than compound $\mathbf{1 4}$ (inactive).

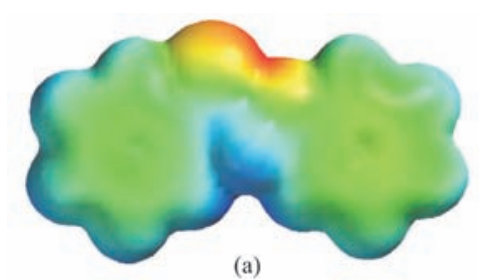

(a)

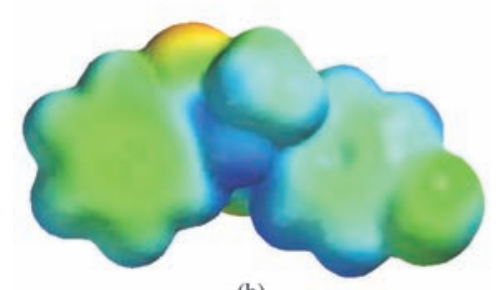

(b)

Figure 8. MEP surfaces of (a) compound $\mathbf{1}$ (active) and (b) compound 17 (inactive). The increase of negative charges goes from positive (green) to negative.

\section{SDA for the Leishmania amazonensis activity}

For this activity the molecules were also classified in two groups: active molecules $(\mathbf{1 - 8}, \mathbf{1 0 - 1 3}, \mathbf{1 5 - 1 8})$ and inactive molecules $(\mathbf{9}, 14$ and 19$)$. The most significant descriptors selected by SDA were obtained with nineteen compounds and is given in equation 3 and equation 4 :

Inactive compounds $=-6.21-3.40 \mathrm{Clog} \mathrm{P}+2.87 \mathrm{Q} 1+$ 5.25 Q2 - 4.20 Q1'

Active compounds $=-0.22+0.64 \mathrm{Clog} \mathrm{P}-0.54 \mathrm{Q} 1-0.98$ $\mathrm{Q} 2+0.79 \mathrm{Q} 1$ ' 
Table 7. Classification matrix obtained using the SDA method for L. amazonensis activity

\begin{tabular}{lccc}
\hline \multirow{2}{*}{ Classified group } & $\%$ & Inactivity & Activity \\
\hline Inactivity & 100 & 3 & 0 \\
Activity & 100 & 0 & 16 \\
Total & 100 & 3 & 16 \\
\hline
\end{tabular}

In such case, the four descriptors (ClogP and charges on 1, 2 and 1'substituent in the carbon atoms) represent the strength of a molecular association by electronic interaction. By using the quantities given in the discriminant functions above, we can obtain the classification summary showed in Table 7. The classification error rate was zero, resulting in a satisfactory separation of the two groups.

In accordance with equations 3 and 4 and Table 3 , we can observe that, in general, molecules with more negative charge on $\mathrm{C} 1$ and $\mathrm{C} 2$ atoms are actives, while more positive charge on $\mathrm{C}^{\prime}$ ' atom are inactives. In addition, Figure 9 shows that, in general, molecules with more positive values for Q1' charge are actives, and the molecules with more negative values for $\mathrm{Q} 1$ ' charge are inactives. The $\mathrm{C} \log \mathrm{P}$ is a measure of hydrophobicity; molecules with large value of $\mathrm{C} \log \mathrm{P}$ have higher hydrophobicity and consequently better transport through cell membranes. In general, we can observe that molecules with high $C \log \mathrm{P}$ values are active, while the molecules with low values of $\mathrm{Clog} P$ are inactive (see supplementary material Figure S3). In other words, the hydrophobic character of molecules improves to $L$. amazonensis activity, what can indicate that the active compounds must interact with a target system such as an enzyme or receptor where the binding site is usually hydrophobic.

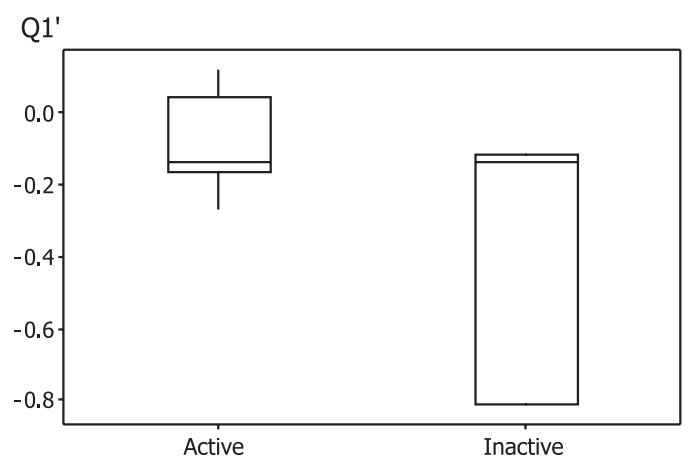

Figure 9. Box plot of L. amazonensis activity for Q1' considering nineteen neolignan compounds.

In order to verify if a new molecule would be active or inactive against L. amazonensis, we need to apply the results obtained with discriminant functions for the molecule 20. From the results obtained in this work we can conclude that the models attained here with SDA can be applied to new neolignans compounds whose biological activity is unknown.

In Figure 10 we can observe that compound $\mathbf{2}$ (active) provides a much more intense region of negative electrostatic potential than compound 9 (inactive), thus compound $\mathbf{2}$ has a more attractive cation-binding site. In general, we observed that active compounds have more intense region of negative electrostatic potential than inactive ones.

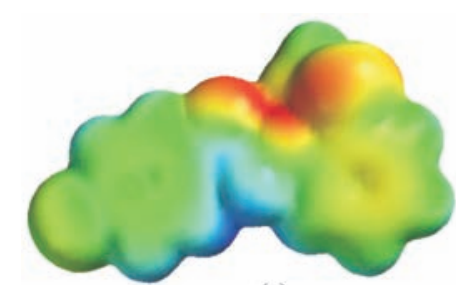

(a)

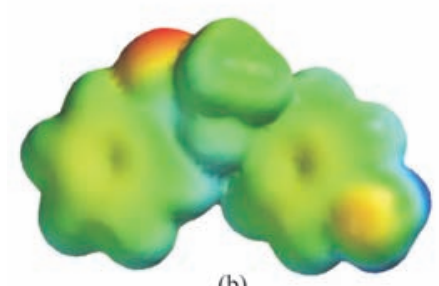

(b)

Figure 10. MEP surfaces of (a) compound 2 (active) and (b) compound 9 (inactive). The increase of negative charges goes from positive (green) to negative.

\section{Conclusions}

We have carried out a synthesis and X-ray crystallographic investigation of the molecular structures of compounds 12 and 20. No significant differences were found in the bond distances and angles of the two molecules. The most relevant structural difference is that the structure of $\mathbf{2 0}$ is almost planar, while the structure of $\mathbf{1 2}$ is itself twisted out of the plane of the aromatic rings. The results show that the agreement between theory and X-ray diffraction data is excellent. In fact the structure geometrics used in theoretical studies are more stable conformers; suggest that calculated structures for molecules $\mathbf{1 2}$ and $\mathbf{2 0}$ are the global minimums. In addition, the SDA method is quite efficient to classify the nineteen neolignans studied here in two groups, actives and inactives, according to their antileishmanials activities, and only some descriptors as atomic charges in positions 1 (Q1), 2 (Q2), 6 (Q6), O or S, 1' (Q1') and 5' (Q5') atoms, the electronic affinity (EA) and $\mathrm{C} \log \mathrm{P}$ are responsible for the separation between the active and inactive compounds. Four different sets of descriptors 
were found to correlate with the two different biological activities, which may indicate that the interaction between the receptor and the binding site and/or mode of action must depend on the type of biological activity.

\section{Supplementary Information}

CCDC 703864 and CCDC 703867 contain the supplementary crystallographic data for this paper. These data can be obtained free of charge at www.ccdc. can.ac.uk/conts/retrieving.html or from the Cambridge Crystallographic Data Center (CCDC), 12 Union Road, Cambridge CB2 1EZ, UK; fax: +44(1233)336-033; e-mail: deposit@ccdc.can.ac.uk.

Other informations are available free of charge at http://jbcs.sbq.org.br, as pdf file.

\section{Acknowledgments}

The authors would like to thank CAPES, CNPq and FINEP (Brazilian agencies) for the financial support in this work.

\section{References}

1. Desjeux, P.; Clin. Dermatol. 1996, 14, 417.

2. Desjeux, P.; Comp. Immunol. Microbiol. Infect. Dis. 2004, 27, 305.

3. Boelaert, M.; Rijal, S.; Regmi, S.; Singh, R.; Karki, B.; Jacquet, D.; Chappuis, F.; Campino, L.; Desjeux, P.; Le Ray, D.; Koirala, S.; Van Der Stuyft, P.; Am. J. Trop. Med. Hyg. 2004, 70, 72.

4. Herwaldt, B. L.; Lancet 1999, 354, 1191.

5. Murray, H. W.; Berman, J. D.; Davies, C. R.; Saravia, N. G.; Lancet 2005, 366, 1561.

6. Reithinger, R.; Coleman, P. G.; Bmc Infect. Dis. 2007, 7, 3.

7. Reithinger, R.; Dujardin, J. C.; J. Clin. Microbiol. 2007, 45, 21.

8. Reithinger, R.; Dujardin, J. C.; Louzir, H.; Pirmez, C.; Alexander, B.; Brooker, S.; Lancet Infect. Dis. 2007, 7, 581.

9. Rijal, S.; Chappuis, F.; Singh, R.; Bovier, P. A.; Acharya, P.; Karki, B. M. S.; Das, M. L.; Desjeux, P.; Loutan, L.; Koirala, S.; Trans. Royal Soc. Trop. Med. Hyg. 2003, 97, 350.

10. Coler, R. N.; Reed, S. G.; Trends Parasitol. 2005, 21, 244.

11. Cook, G. C.; J. Antimicrob. Chemother. 1993, 31, 327.

12. Croft, S. L.; Coombs, G. H.; Trends in Parasitol. 2003, 19, 502.

13. Olliaro, P. L.; Bryceson, A. D. M.; Parasitol. Today 1993, 9, 323.

14. Aveniente, M.; Pinto, E. F.; Santos, L. S.; Rossi-Bergmann, B.; Barata, L. E. S.; Bioorg. Med. Chem. 2007, 15, 7337.

15. Barata, L. E. S.; Santos, L. S.; Ferri, P. H.; Phillipson, J. D.; Paine, A.; Croft, S. L.; Phytochemistry 2000, 55, 589.

16. Gottlieb, O. R.; Mem. Inst. Oswaldo Cruz 1991, 86, 25.

17. Zacchino, S.; Rodriguez, G.; Pezzenati, G.; Orellana, G.; Enriz, R.; Sierra, M. G.; J. Nat. Prod. 1997, 60, 659.
18. Zacchino, S.; Rodriguez, G.; Santecchia, C.; Pezzenati, G.; Giannini, F.; Enriz, R.; J. Ethnopharmacol. 1998, 62, 35.

19. Zacchino, S. A.; Lopez, S. N.; Pezzenati, G. D.; Furlan, R. L.; Santecchia, C. B.; Munoz, L.; Giannini, F. A.; Rodriguez, A. M.; Enriz, R. D.; J. Nat. Prod. 1999, 62, 1353.

20. Alves, C. N.; Barroso, L. P.; Santos, L. S.; Jardim, I. N.; J. Braz. Chem. Soc. 1998, 9, 577.

21. Alves, C. N.; de Macedo, L. G. M.; Honorio, K. M.; Camargo, A. J.; Santos, L. S.; Jardim, I. N.; Barata, L. E. S.; da Silva, A. B. F.; J. Braz. Chem. Soc. 2002, 13, 300.

22. Braga, A. C. H.; Zacchino, S.; Badano, H.; Sierra, M. G.; Ruveda, E. A.; Phytochemistry 1984, 23, 2025.

23. Isogai, A.; Suzuki, A.; Tamura, S.; Murakosh, S.; Agric. Biol. Chem. 1973, 37, 1479.

24. Kraft, C.; Jenett-Siems, K.; Kohler, I.; Tofern-Reblin, B.; Siems, K.; Bienzle, U.; Eich, E.; Phytochemistry 2002, 60, 167.

25. Abe, F.; Nagafuji, S.; Yamauchi, T.; Okabe, H.; Maki, J.; Higo, H.; Akahane, H.; Aguilar, A.; Jimenez-Estrada, M.; ReyesChilpa, R.; Biol. Pharm. Bull. 2002, 25, 1188.

26. Luize, P. S.; Ueda-Nakamura, T.; Dias, B. P.; Cortez, D. A. G.; Nakamura, C. V.; Biol. Pharm. Bull. 2006, 29, 2126.

27. Nocito, I.; Castelli, M. V.; Zacchino, S. A.; Serra, E.; Parasitol. Res. 2007, 101, 1453.

28. Lima, O. A.; Magalhães, M. T.; Gottlieb, O. R.; Phytochemistry 1972, 11, 2031.

29. Barata, L. E. S.; Santos, L. S.; Fernandes, A. M. A. P.; Ferri, P. H.; Queiroz, M.; Neal, R.; Jourdan, M. C.; Abstracts of II Brazilianisch-Deustsches Symposium für Naturstoffchemie, Hannover, Germany, 1991.

30. Sartorelli, P.; Benevides, P. J. C.; Ellensohn, R. M.; Rocha, M. V. A. F.; Moreno, P. R. H.; Kato, M. J.; Plant Sci. 2001, 161, 1083.

31. Son, Y. K.; Lee, M. H.; Han, Y. N.; Arch. Pharmacal Res. 2005 , $28,34$.

32. Konya, K.; Varga, Z.; Antus, S.; Phytomedicine 2001, 8, 454.

33. Lee, W. S.; Baek, Y. I.; Kim, J. R.; Cho, K. H.; Sok, D. E.; Jeong, T. S.; Bioorg. Med. Chem. Lett. 2004, 14, 5623.

34. Camargo, A. J.; Mercadante, R.; Honorio, K. M.; Alves, C. N.; da Silva, A. B. F.; J. Mol. Struct. 2002, 583, 105.

35. Ferri, P. H.; Barata, L. E. S.; Phytochemistry 1992, 31, 1375.

36. Camargo, A. J.; Honorio, K. M.; Mercadante, R.; Molfetta, F. A.; Alves, C. N.; da Silva, A. B. F.; J. Braz. Chem. Soc. 2003, $14,809$.

37. Pinheiro, A. A. C.; Borges, R. S.; Santos, L. S.; Alves, C. N.; J. Mol. Struct. 2004, 672, 215.

38. Alves, C. N.; Pinheiro, J. C.; Camargo, A. J.; de Souza, A. J.; Carvalho, R. B.; da Silva, A. B. F.; J. Mol. Struct. 1999, 491, 123.

39. Dias, J. C.; Rebelo, M. M.; Alves, C. N.; J. Mol. Struct. 2004, $676,83$.

40. Lameira, J.; Alves, C. N.; Moliner, V.; Marti, S.; Kanaan, N.; Tunon, I.; J. Phys. Chem. B 2008, 112, 14260. 
41. Lameira, J.; Alves, C. N.; Moliner, V.; Silla, E.; Eur. J. Med. Chem. 2006, 41, 616.

42. Reis, M.; Lobato, B.; Lameira, J.; Santos, A. S.; Alves, C. N.; Eur. J. Med. Chem. 2007, 42, 440.

43. Alves, C. N.; Pinheiro, J. C.; Camargo, A. J.; Ferreira, M. M. C.; Romero, R. A. F.; da Silva, A. B. F.; J. Mol. Struct. 2001, 541,81 .

44. Lameira, J.; Medeiros, I. G.; Reis, M.; Santos, A. S.; Alves, C. N.; Bioorg. Med. Chem. 2006, 14, 7105.

45. Molfetta, F. A.; Honorio, K. M.; Alves, C. N.; da Silva, A. B. F.; J. Mol. Struct. 2004, 674, 191.

46. North, A. C. T.; Phillips, D. C.; Mathews, F. S.; Acta Crystallogr, Sect. A: Found. Crystallogr. 1968, 24, 351.

47. Altomare, A.; Cascarano, G.; Giacovazzo, C.; Guagliardi, A.; J. Appl. Crystallogr. 1993, 26, 343.

48. Sheldrick, G. M.; SHELXS-97: Program for the Solution of Crystal Structures, University of Gottingen, Germany, 1997.

49. Farrugia, L. J.; J. Appl. Crystallogr. 1999, 32, 837.

50. Speck, A. L.; PLATON: A Multipurpose Crystallographic Tool, Utrecht University: The Netherlands, 1998.

51. Farrugia, L. J.; J. Appl. Crystallogr. 1997, 30, 565.

52. Becke, A. D.; Phys. Rev. A: At., Mol., Opt. Phys. 1988, 38, 3098.

53. Lee, C. T.; Yang, W. T.; Parr, R. G.; Phys. Rev. B: Condens. Matter Mater. Phys. 1988, 37, 785.

54. Frisch, M. J.; Trucks, G. W.; Schlegel, H. B.; Scuseria, G. E.; Robb, M. A.; Cheeseman, J. R.; Montgomery, J. A. J.; Vreven, T.; Kudin, K. N.; Burant, J. C.; Millam, J. M.; Iyengar, S. S.; Tomasi, J.; Barone, V.; Mennucci, B.; Cossi, M.; Scalmani, G.; Rega, N.; Petersson, G. A.; Nakatsuji, H.; Hada, M.; Ehara, M.; Toyota, K.; Fukuda, R.; Hasegawa, J.; Ishida, M.; Nakajima, T.; Honda, Y.; Kitao, O.; Nakai, H.; Klene, M.; Li, X.; Knox, J. E.; Hratchian, H. P.; Cross, J. B.; Adamo, C.; Jaramillo, J.; Gomperts, R.; Stratmann, R. E.; Yazyev, O.; Austin, A. J.; Cammi, R.; Pomelli, C.; Ochterski, J. W.; Ayala, P. Y.; Morokuma, K.; Voth, G. A.; Salvador, P.; Dannenberg, J. J.; Zakrzewski, V. G.; Dapprich, S.; Daniels, A. D.; Strain, M. C.; Farkas, O.; Malick, D. K.; Rabuck, A. D.; Raghavachari, K.; Foresman, J. B.; Ortiz, J. V.; Cui, Q.; Baboul, A. G.; Clifford, S.; Cioslowski, J.; Stefanov, B. B.; Liu, G.; Liashenko, A.; Piskorz, P.; Komaromi, I.; Martin, R. L.; Fox, D. J.; Keith, T.; Al-Laham,
M. A.; Peng, C. Y.; Nanayakkara, A.; Challacombe, M.; Gill, P. M. W.; Johnson, B.; Chen, W.; Wong, M. W.; Gonzalez, C.; Pople, J. A.: Gaussian 03, Revision B.04; Gaussian, Wallingford, CT, 2004.

55. Olivato, P. R.; Domingues, N. L. C.; Mondino, M. G.; Lima, F. S.; Zukerman-Schpector, J.; Rittner, R.; Dal Colle, M.; J. Mol. Struct. 2008, 892, 360.

56. Olivato, P. R.; Domingues, N. L. C.; Mondino, M. G.; Tormena, C. F.; Rittner, R.; Dal Colle, M.; J. Mol. Struct. 2009, 920, 393.

57. Olivato, P. R.; Domingues, N. L. C.; Reis, A. K. C. A.; Vinhato, E.; Mondino, M. G.; Zukerman-Schpector, J.; Rittner, R.; Dal Colle, M.; J. Mol. Struct. 2009, 935, 60.

58. Parr, R. G.; Donnelly, R. A.; Levy, M.; Palke, W. E.; J. Chem. Phys. 1978, 68, 3801.

59. Labbe, S.; Bertin, P. Y.; J. Magn. Magn. Mat. 1999, 206, 93.

60. Koopmans, T.; Physica 1933, 1, 104.

61. Wright, J. S.; Carpenter, D. J.; McKay, D. J.; Ingold, K. U.; J. Am. Chem. Soc. 1997, 119, 4245.

62. HyperChem ${ }^{\mathrm{TM}}$; Release 7.5 for Windows Molecular Modeling System; Hypercube, Florida, USA, 2002.

63. Chem3D Ultra 6.0; CambridgeSoft.Com, Cambridge, MA, USA, 2005.

64. MINITAB Release 14 for Windows; Minitab, State College, PA, 2003.

65. PC Spartan-Pro, version 1.0; Wavefunction, Inc., Irvine, CA, USA, 1999.

66. Alves, C. N.; Castilho, M.; Mazo, L. H.; Tabak, M.; da Silva, A. B. F.; Chem. Phys. Lett. 2001, 349, 146.

67. Brasil, D. S. B.; Moreira, R. Y. O.; Muller, A. H.; Alves, C. N.; Int. J. Quantum Chem. 2006, 106, 2706.

68. Brasil, D. S. B.; Müller, A. H.; Guilhon, G. M. S. P.; Alves, C. N.; Peris, G.; Llusar, R.; Moliner, V.; J. Braz. Chem. Soc. 2010, 21,731 .

69. Domingo, L. R.; Andres, J.; Alves, C. N.; Eur. J. Org. Chem. 2002, 2557.

Submitted: August 28, 2009

Published online: June 16, 2010

FAPESP has sponsored the costs of this publication. 


\title{
Synthesis, X-ray Crystal Structure and Theoretical Calculations of Antileishmanial Neolignan Analogues
}

\author{
Josenaide P. do Nascimento, ${ }^{a}$ Lourivaldo S. Santos, ${ }^{a}$ Regina Helena A. Santos, ${ }^{b}$ \\ Érica Tozzo, ${ }^{b}$ Janaina G. Ferreira, ${ }^{b, c}$ Maria Carolina L. do Carmo, ${ }^{a}$ \\ Davi S. B. Brasil ${ }^{a}$ and Cláudio N. Alves $*, a$
}
${ }^{a}$ Instituto de Ciências Exatas e Naturais, Universidade Federal do Pará, Rua Augusto Corrêa 01, 66075-110 Belém-PA, Brazil

${ }^{b}$ Instituto de Química de São Carlos, Universidade de São Paulo, Av. do Trabalhador São-carlense 400, CP 780, 13560-970 São Carlos-SP, Brazil

${ }^{c}$ Instituto de Química de Araraquara, Universidade Estadual Paulista, Rua Francisco Degni s/n, 14800-900 Araraquara-SP, Brazil

CCDC 703864 and CCDC 703867 contain the supplementary crystallographic data for this paper. These data can be obtained free of charge at www.ccdc.can.ac.uk/conts/retrieving.html or from the Cambridge Crystallographic Data Center (CCDC), 12 Union Road, Cambridge CB2 1EZ, UK; fax: +44(1233)336-033; e-mail: deposit@ ccdc.can.ac.uk.

Table S1. Scan step number and energy of the conformers calculated by DFT B3LYP/6-31G* for molecules 12 and 20

\begin{tabular}{|c|c|c|c|c|c|c|c|}
\hline \multicolumn{2}{|c|}{ Molecule $\mathbf{1 2}$} & \multicolumn{2}{|c|}{ Molecule 20} & \multicolumn{2}{|c|}{ Molecule 12} & \multicolumn{2}{|c|}{ Molecule $\mathbf{2 0}$} \\
\hline $\begin{array}{l}\text { Scan step } \\
\text { number }\end{array}$ & $\begin{array}{c}\text { Energy } \\
\text { (Hartree) }\end{array}$ & $\begin{array}{c}\text { Scan step } \\
\text { number }\end{array}$ & $\begin{array}{c}\text { Energy } \\
\text { (Hartree) }\end{array}$ & $\begin{array}{l}\text { Scan step } \\
\text { number }\end{array}$ & $\begin{array}{c}\text { Energy } \\
\text { (Hartree) }\end{array}$ & $\begin{array}{c}\text { Scan step } \\
\text { number }\end{array}$ & $\begin{array}{c}\text { Energy } \\
\text { (Hartree) }\end{array}$ \\
\hline $0.86^{\mathrm{a}}$ & -1742.08 & $0.83^{\mathrm{a}}$ & -1150.74 & 19.04 & -1742.04 & 18.82 & -1150.74 \\
\hline 1.84 & -1742.08 & 1.80 & -1150.74 & 19.89 & -1741.91 & 20.07 & -1150.74 \\
\hline 2.82 & -1742.08 & 2.91 & -1150.74 & 20.88 & -1742.07 & 21.18 & -1150.74 \\
\hline 3.93 & -1742.08 & 3.88 & -1150.74 & 22.11 & -1742.04 & 22.01 & -1150.74 \\
\hline 4.91 & -1742.08 & 4.98 & -1150.74 & 22.96 & -1742.03 & 23.11 & -1150.74 \\
\hline 6.14 & -1742.08 & 5.67 & -1150.74 & 23.70 & -1742.04 & 24.08 & -1150.74 \\
\hline 7.00 & -1742.07 & 7.06 & -1150.74 & 24.93 & -1742.05 & 24.91 & -1150.73 \\
\hline 7.98 & -1742.08 & 7.89 & -1150.74 & 26.16 & -1742.05 & 25.88 & -1150.73 \\
\hline 8.84 & -1742.06 & 9.00 & -1150.74 & 26.89 & -1742.06 & 26.99 & -1150.73 \\
\hline 9.82 & -1742.03 & 9.97 & -1150.74 & 28.12 & -1742.06 & 27.96 & -1150.74 \\
\hline 11.05 & -1742.05 & 10.93 & -1150.74 & 28.86 & -1742.05 & 28.93 & -1150.73 \\
\hline 12.16 & -1742.07 & 11.90 & -1150.74 & 29.96 & -1742.06 & 29.90 & -1150.72 \\
\hline 13.02 & -1741.93 & 13.01 & -1150.74 & 30.95 & -1742.07 & 30.87 & -1150.71 \\
\hline 14.12 & -1742.03 & 13.98 & -1150.74 & 32.18 & -1742.06 & 31.70 & -1150.72 \\
\hline 14.86 & -1742.05 & 14.81 & -1150.74 & 33.16 & -1742.06 & 33.08 & -1150.73 \\
\hline 15.84 & -1742.06 & 15.78 & -1150.74 & 33.89 & -1742.05 & 34.05 & -1150.73 \\
\hline 16.82 & -1742.06 & 16.89 & -1150.74 & & & 35.02 & -1150.73 \\
\hline 18.05 & -1742.06 & 17.99 & -1150.74 & & & 36.26 & -1150.73 \\
\hline
\end{tabular}

${ }^{a}$ Structures optimized with the 6-311++G( $\left.d, p\right)$ basis sets using X-ray diffraction data.

*e-mail: nahum@ufpa.br 


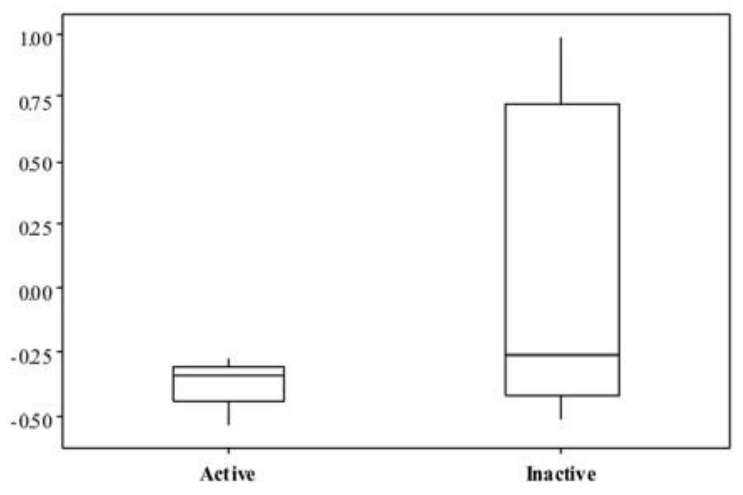

Figure S1. Box plot of $L$. donovani activity for $\mathrm{O}$ or $\mathrm{S}$ atom considering nineteen neolignan compounds.

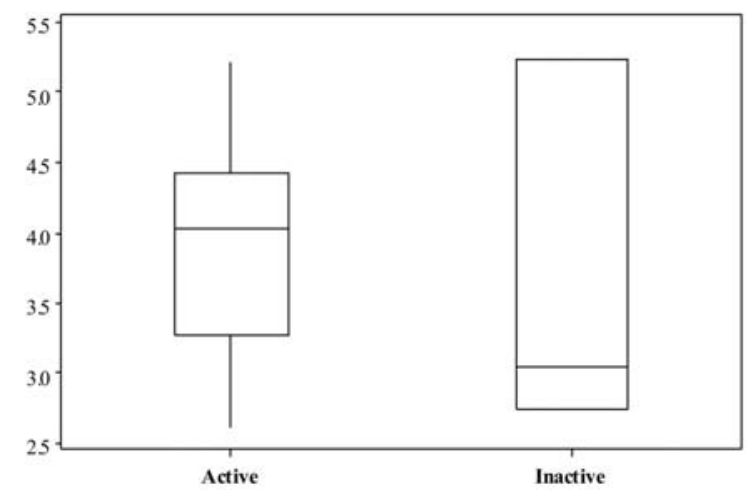

Figure S3. Box plot of L. amazonensis activity for ClogP considering nineteen neolignan compounds.

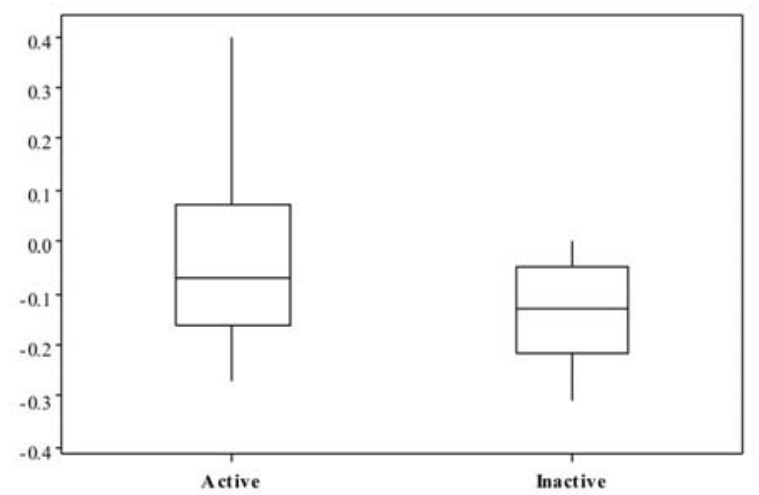

Figure S2. Box plot of $L$. donovani activity for Q5' considering nineteen neolignan compounds.

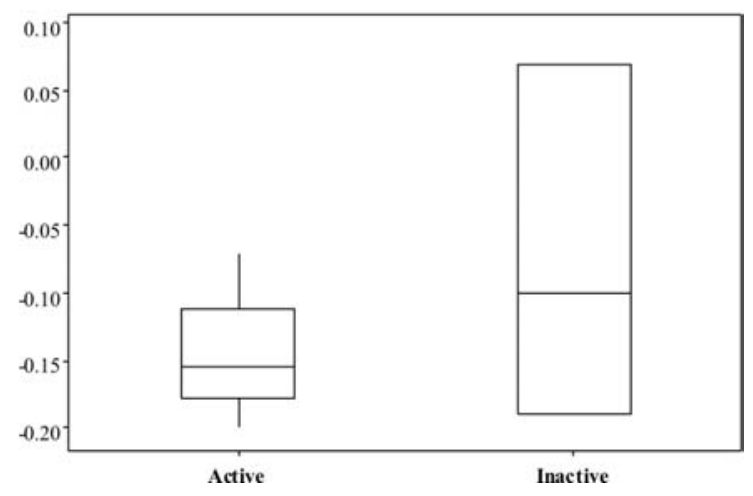

Figure S4. Box plot of L. amazonensis activity for Q2 considering nineteen neolignan compounds.

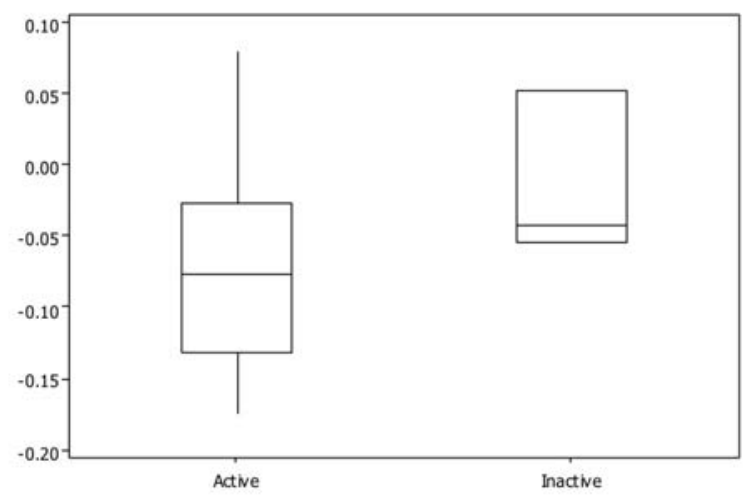

Figure S5. Box plot of L. amazonensis activity for Q1 considering nineteen neolignan compounds. 